\title{
THE EFFECT OF ENTREPRENEURSHIP EDUCATION AND FAMILY ENVIRONMENT ON ENTREPRENEURIAL INTERESTS THROUGH SELF-EFFICACY
}

\author{
Riva Karomatul Azizah ${ }^{1}$, Triesninda Pahlevi ${ }^{2}$ \\ ${ }^{1,2,3}$ Universitas Negeri Surabaya, Surabaya, Indonesia \\ ${ }^{1}$ Rivaazizah05@gmail.com, ${ }^{2}$ Triesnindapahlevi@gmail.com
}

\begin{abstract}
This research aimed to measure the effect of entrepreneurship education on entrepreneurial interest, the family environment on entrepreneurial interest, entrepreneurship education on self-efficacy, the family environment on self-efficacy, self-efficacy on entrepreneurial interest, and entrepreneurship education on entrepreneurial interest mediated by self-efficacy, as well as the family environment on the entrepreneurial interest mediated by selfefficacy. This research was conducted on students of Office Administration Education Study Program at Universitas Negeri Surabaya registered in 2018 which consisted of 62 students. All populations were used as samples in this research. This research technique was quantitative research with causal associative types and primary data types. Data were collected by using Self-Administered Surveys. Then, the data were analyzed by using path analysis. The research output concluded that entrepreneurship education did not have a positive impact on entrepreneurial interest $(P$ Value $=0.789)$, the family environment had a positive and significant impact on entrepreneurial interest $(P$ Value $=0.030)$, self-efficacy had a positive impact on entrepreneurial interest $(P$ Value $=0.000)$, entrepreneurship education had a positive and significant impact on self-efficacy $(P$ Value $=0.000)$, family environment had a positive and significant impact on self-efficacy $(P$ Value $=0.044)$, entrepreneurship education had a positive and significant impact on entrepreneurial interest mediated by self-efficacy $(P$ Value $=0.000)$, family environment did not have a positive and significant impact on the entrepreneurial interest mediated by self-efficacy $(P$ Value $=0.107)$.
\end{abstract}

Keywords: entrepreneurial interest, entrepreneurship education, family environment, self-efficacy

\section{PENGARUH PENDIDIKAN KEWIRAUSAHAAN DAN LINGKUNGAN KELUARGA TERHADAP MINAT BERWIRAUSAHA MELALUI SELF-EFFICACY}

\begin{abstract}
ABSTRAK
Riset ini bertujuan untuk mengukur dampak pendidikan kewirausahaan ke peminatan berwirausaha, lingkungan keluarga ke peminatan berwirausaha, pendidikan kewirausahaan ke self-efficacy, lingkungan keluarga ke self-efficacy, self-efficacy ke peminatan berwirausaha, pendidikan kewirausahaan ke peminatan berwirausaha yang dimediasi self-efficacy, lingkungan keluarga ke peminatan berwirausaha yang dimediasi self-efficacy. Riset ini dilakukan pada Mahasiswa angkatan 2018 Program Studi Pendidikan Administrasi Perkantoran Universitas Negeri Surabaya yang berjumlah 62 mahasiswa. Semua populasi digunakan sampel di riset ini, teknik riset ini menggunakan riset secara kuantitatif dengan jenis asosiatif kausal dan jenis data primer. Teknik pengumpulan data menggunakan Self- Administered Surveys. Teknik analisa memakai analisis jalur. Output riset memberi kesimpulan pendidikan kewirausahaan ke minat berwirausaha tidak memiliki dampak positif ( $\mathrm{P}$ Value $=0.789$ ), lingkungan keluarga berdampak positif dan signifikan ke minat berwirausaha $(P$ Value $=0.030)$, self-efficacy ada dampak positif ke minat berwirausaha $(P$ Value $=0.000)$, pendidikan kewirausahaan ada dampak positif dan signifikan ke self-efficacy $(\mathrm{P}$ Value $=0.000)$, lingkungan keluarga ada dampak positif dan signifikan ke selfefficacy $(\mathrm{P}$ Value $=0.044)$, pendidikan kewirausahaan ke minat berwirausaha yang dimediasi self-efficacy memiliki dampak positif dan signifikan $(\mathrm{P}$ Value $=0.000)$, lingkungan keluarga ke minat berwirausaha yang dimediasi self-efficacy tidak memberi dampak positif dan signifikan $(\mathrm{P}$ Value $=$ $0.107)$.
\end{abstract}

Kata Kunci: minat berwirausaha, pendidikan kewirausahaan, lingkungan keluarga, self-efficacy

\begin{tabular}{|c|c|c|}
\hline Submitted & Accepted & Published \\
\hline 21 Mei 2021 & 09 Agustus 2021 & 14 September 2021 \\
\hline
\end{tabular}

\begin{tabular}{|l|l|r|l|}
\hline Citation & $:$ & $\begin{array}{r}\text { Azizah, R. K., \& Pahlevi, T. (2021). The Effect of Entrepreneurship Education and Family Environment on } \\
\text { Entrepreneurial Interests through Self-Efficacy. Jurnal PAJAR (Pendidikan dan Pengajaran), 5(5), 1188-1201. } \\
\text { DOI : http://dx.doi.org/10.33578/pjr.v5i5.8417. }\end{array}$ \\
\hline
\end{tabular}

\section{PENDAHULUAN}

Pengangguran ialah problem yang cukup serius dan urgent di Indonesia, ini timbul dan tumbuh karena tidak seimbangnya antara total angkatan kerja dan pekerja yang tersedia dengan lapangan pekerjaan pada setiap tahun. Pernyataan tersebut sejalan dan sependapat dengan penelitian dari Harjanto (2014) menyatakan bahwa pengangguran akan selalu ada dan muncul dalam 
perekonomian modern karena terdapat kesenjangan ataupun perbedaan antara penawaran tenaga yang tersedia dengan permintaan tenaga kerja yang ada di lapangan hingga dibutuhkan penambahan jumlah lapangan pekerjaan untuk mengurangi dan menimalisir total pengangguran yang ada. Menjadi seorang pengangguran bukanlah hasil dari sebuah pilihan akan tetapi pengangguran terjadi akibat sulitnya dalam bentuk persaingan yang harus dilakukan dan realitanya serta mereka belum mendapatkan kesempatan berupa peluang untuk bekerja. Hal ini berdampak vital pada masalah lainnya seperti kemiskinan, kriminalitas dan meningkatnya pekerja seks komersial di kalangan muda (Franita, 2016).

Pengangguran di Indonesia semakin meningkat pesat. Hal ini dikarenakan bukan tanpa sebab, yakni bentuk dampak dari wabah penyakit covid-19. Banyak perusahaan dan lapangan kerja yang merumahkan atau dengan kata lain melakukan PHK besar-besaran yang ditujukan ke para pegawainya dan tidak membuka lagi lapangan pekerjaan baru untuk calon-calon pegawai perusahaan yang baru, sehingga semakin berkurangnya kesempatan berupa peluang pekerjaan bagi mereka yang belum mendapatkan pekerjaan ataupun bagi mahasiswa yang lulus kuliah saat masa-masa pandemi seperti sekarang ini, terlebih bagi mereka yang baru lulus dari perguruan tinggi. Sesuai data acuan yang diterbitkan oleh Badan Pusat Statistik (2020) menyatakan bahwa angka pengangguran pada tahun 2020 atau saat masa-masa pandemi seperti ini meningkat dari tahun sebelumnya tercatat di data bahwa pada bulan Agustus 2020 pengangguran di Indonesia memperoleh angka yang cukup tinggi sebesar 5,84 persen, meningkat 2,02 persen untuk tingkat pengangguran terbuka dari bulan Agustus 2019 sehingga terdapat pertambahan jumlah yang cukup signifikan sejumlah 466,02 ribu orang yang menganggur.

Di masa ini, generasi muda perlu merubah cara pandang dan pola pikir jangan hanya menjadi seorang pegawai setelah lulus namun menjadi wirausaha yang membuka lapangan kerja perlu dipikirkan sebagai pilihan. Menjadi seorang pegawai bukan suatu kesalahan, akan tetapi menjadi wirausaha yang dapat menciptakan peluang pekerjaan untuk orang lain akan lebih baik. Apabila alumni-alumni D1, D2, D3, S1, S2 maupun S3 memiliki semangat wirausaha maka para lulusan itu tidak bisa menjadi pengangguran (Hanum, 2014). Pemerintah melalui kebijakannya dalam pendidikan diharapkan dapat merubah pola pikir mahasiswa tidak hanya menjadi pegawai melainkan mereka berminat untuk menjadi wirausaha. Satu bagian psikis manusia untuk menstimulus seseorang mencapai visi adalah minat (Mugiyatun \& Khafid, 2020). Siswa yang condong terdorong untuk memahami dan menggali perihal-perihal yang diminati tanpa ada rasa keterpaksaan berarti siswa tersebut sudah memiliki minat dalam dirinya (Sugiyanti, 2019).

Pendidikan merupakan sebuah sarana yang penting sebagai bekal untuk mendapatkan pekerjaan sehingga banyak orang tua yang menganggap bahwa semakin tinggi pendidikan merupakan sebuah peluang mendapat pekerjaan yang layak untuk kedepannya, namun pada kenyataanya banyak lulusan perguruan tinggi yang masih belum memiliki pekerjaan. Ini terjadi akibat kurangnya kompetensi yang dimiliki mahasiswa akibat sistem pendidikan yang sangat teoritis hingga keterampilan yang mestinya dipunyai untuk dunia kerja tidak bisa dimaksimalkan (Mutmainnah dkk., 2020). Selain itu generasi muda condong tidak termotivasi jadi wirausaha ini disebabkan kurangnya peminatan berwirausaha. Oleh sebab itu dibutuhkan sebuah motivasi dengan manambah ajaran program mata kuliah pendidikan kewirausahaan. Karena pada saat pendidikan wirausaha mahasiswa diberi peluang untuk membuat sebuah produk yang kreatif. Dengan tujuan sesudah ikut serta dalam pembelajaran ini mahasiswa memiliki minat di wirausaha.

Adapun tujuan dari riset ini guna mencari: (1) dampak Pendidikan Kewirausahaan ke Minat Berwirausaha; (2) dampak Lingkungan Keluarga ke Minat Berwirausaha; (3) Dampak Self-Efficacy ke Minat Berwirausaha; (4) dampak Pendidikan Kewirausahaan ke Self-Efficacy; (5) dampak Lingkungan Keluarga ke Self-Efficacy; (6) dampak Pendidikan Kewirausahaan ke Minat Berwirausaha yang di mediasi oleh Self-Efficacy; 
(7) dampak Lingkungan Keluarga ke Minat Berwirausaha yang di mediasi oleh Self-Efficacy.

\section{KAJIAN TEORETIS \\ Minat Berwirausaha}

Ketika mengerjakan sesuatu perlu didasari oleh minat, semakin besar minat maka dapat mendorong seseorang melakukan kegiatan tanpa ada paksaan. Minat berwirausaha merupakan ketertarikan dalam diri seseorang untuk membuat usaha yang kemudian dikelola dan dikembangkan serta mau menghadapi resiko (Suryana, 2006). Sedangkan menurut Rahmadi \& Heryanto (2016) peminatan berwirausaha ialah rasa ingin tahu seseorang dalam berperilaku kerja, menemui kegagalan dan resiko untuk mencukupi kebutuhannya, sehingga dapat disimpulkan minat berwirausaha ialah kecondongan seseorang dalam membuat usaha yang mau menerima segala resiko yang akan dihadapi serta mau mempelajari dan menjalankan hal itu dengan tidak ada rasa keterpaksaan.

\section{Pendidikan Kewirausahaan}

Pendidikan Kewirausahaan dapat dilakukan untuk mendorong peserta didik untuk menumbuhkan minat berwirausaha. Pendidikan dapat menjadikan pengetahuan individu jadi lebih percaya diri, dapat memutuskan, dan membuat pilihan secara tepat, serta menambah berpikir kreatif dan inovatif dapat membimbing moral, karakter, dan intelektual (Mugiyatun \& Khafid, 2020). Wirausaha adalah suatu usaha seseorang dalam menciptakan produk untuk memenuhi keinginan dan kebutuhannya (Hanum, 2014). Sedangkan menurut Dewi \& Subroto (2020) wirausaha merupakan seseorang yang dapat berfikir secara inovatif dengan ide-ide barunya untuk membuat suatu produk yang berbeda dan menjadi lebih bagus dari sebelumnya, Kewirausahaan merupakan potensi untuk membuat perihal yang inovatif dan beda, lewat berpikir kreatif dan berperilaku inovatif guna membuat peluang ketika menemui rintangan hidup (Wibowo, 2017). Sehingga dapat disimpulkan pendidikan kewirausahaan merupakan upaya yang dilaksanakan agar dapat mengubah pola pikir dan pola pandang terhadap kegiatan wirausaha untuk menginovasi suatu produk agar dapat menghasilkan produk yang menarik dipasaran.

\section{Lingkungan Keluarga}

Satu dari sebab yang ikut mendukung berkembangnya peminatan berwirausaha tidak terlepas dari dampak circle keluarga. Orang tua memiliki kedudukan yang tinggi di lingkungan keluarga sehingga orang tua ikut andil dalam menentukan pandangan tentang pemilihan pekerjaan yang diambil anaknya di masa yang akan datang, tumbuh kembang seorang anak ditentukan oleh cara orang tua mengasuh (Aini dkk., 2015). Dalam hal ini untuk menentukan masa depan anak circle keluarga utamanya orang tua memiliki peran sebagai pengarah, maka dengan cara tidak langsung penentuan peminatan ke pekerjaan anak dipengaruhi oleh orang tua, termasuk dalam hal berwirausaha (Fitriani dkk., 2012). Maka dapat ditarik kesimpulan bahwa lingkungan keluarga sangat berperan penting untuk mempengaruhi sikap atau perilaku seseorang karena lingkungan keluarga adalah pendidikan pertama yang diperoleh seseorang sehingga apa yang dilihat merupakan sebuah pembelajaran yang diberikan kepada orang tersebut.

\section{Self-Efficacy}

Rasa yakin yang berasal diri seorang yang memberi pengaruh tingginya semangat merupakan efikasi diri. Efikasi diri merupakan hal penting bagi seseorang karena keyakinan diri dapat berguna di masa depan atau masa kini (Aini et al., 2015). Rasa percaya diri seseorang atas kemampuannya dalam menyelesaikan tugas ini sangat berpengaruh untuk mendorong semangat dalam dirinya. Tingginya self-efficacy yang dimiliki seseorang juga mempengaruhi tingginya minat seseorang untuk melakukan sesuatu kegiatan (Mugiyatun \& Khafid, 2020). Cerminan pengetahuan individu mengenai potensinya berdasarkan pengalaman di masa lalu terhadap kinerja dan perhatiannya untuk berusaha berasal dari self-efficacy.

\section{METODE PENELITIAN}

Jenis riset ini menggunakan jenis riset asosiatif kausal menggunakan pendekatan kuantitatif dikarenakan data yang dianalisis dalam 
bentuk angka yang dianalisis statistik untuk mencari dampak pendidikan kewirausahaan dan lingkungan keluarga ke minat berwirausaha melalui self-efficacy. Asosiatif kausal ialah riset bersifat sebab-akibat yang bertujuan menganalisis pengaruh ataupun hubungan variabel bebas pada variabel terikat. Penelitian ini dilakukan pada bulan januari 2021 di Program Studi Pendidikan Administrasi Perkantoran Universitas Negeri Surabaya.

Jenis data yang digunakan di riset ini ialah data kuantitatif sedangkan sumber datanya ialah data primer. Data primer ialah data yang didapat langsung lewat responden tentang pendidikan kewirausahan, lingkungan keluarga, selfefficacy dan minat berwirausahaJenis data yang digunakan di riset ini ialah data kuantitatif sedangkan sumber datanya ialah data primer. Data primer ialah data yang didapat langsung lewat responden tentang pendidikan kewirausahan, lingkungan keluarga, self-efficacy dan minat berwirausaha.

Untuk pencarian sampel memakai metode sampling jenuh sehingga semua populasi yang ada digunakan sebagai sampel yaitu Mahasiswa Program Studi Pendidikan Administrasi Perkantoran tahun 2018 yang baru saja menyelesaikan mata kuliah kewirausahaan sehingga diharapkan dapat mendorong minat wirausaha. Jumlah responden sebanyak 62 mahasiswa. Pendidikan kewirausahaan dan lingkungan keluarga adalah variabel bebas, variabel intervening meliputi self-efficacy dan variabel terikat meliputi minat berwirausaha.

Teknik pengumpulan data dilakukan dengan Self- Administered Surveys ini merupakan teknik dengan cara memberi serangkaian pertanyaan ke responden untuk dijawab, pertanyaan ini bersifat tertutup karena pertanyaan disajikan oleh peneliti telah terdapat jawaban alternative sehingga responden hanya perlu memilih jawaban yang telah disajikan (Sugiyono, 2015). Analisis jalur merupakan metode analisis data di riset ini dengan bantuan program smartPLS.

Uji validitas dan reliabilitas dalam penelitian ini dilakukan diluar sampel penelitian, uji ini dilakukan untuk mencari valid dan tidak kuisioner, pertanyaan yang ada di kuisioner haruslah mampu mengukur objek yang dituju agar dapat dinyatakan valid. Instrumen yang valid artinya tolok ukur yang dipakai guna memperoleh data itu valid (Sugiyono, 2015). Kriteria agar instrumen dinyatakan valid harus memenuhi syarat antara lain: Nilai Convergent Validity diharapkan > 0.7 (Hair Jr et al., 2014) Nilai Discriminant Validity bisa ditinjau melalui membandingkan konstruk yang dituju mesti lebih besar dari konstruk lain, dan Nilai AVE haruslah > 0.5 (Urbach \& Ahlemann, 2010)

Adapun prosedur penelitian yang harus dilakukan ini ada 2 tahap yang mesti dilaksanakan yakni pengukuran outer model dan inner model. Tahap yang mesti dilaksanakan dalam pengukuran outer model yakni dapat dilihat dari nilai convergent validity $\geq 0.7$ kemudian discriminant validity nilai tersebut dapat dilihat dari AVE $\geq 0.5$ dan composite reliability dan cronbach alpha $\geq$ 0.60 . Untuk pengujian evaluasi inner model dengan melihat $R$-square pada konstruk dependen , menghitung $Q$-Square dengan perhitungan StoneGeisser Q-Square Test dan pengujian hipotesis dengan ketentuan T-hitung lebih dari 1.960 dan PValue lebih kecil 0.05 agar dapat dinyatakan adanya pengaruh antar variabel laten.

\section{HASIL DAN PEMBAHASAN}

\section{Hasil Model Pengukuran (Outer Model)}

Analisis ini dilakukan untuk mengetahui hasil evaluasi reliabilitas dan validitas konstruk. 


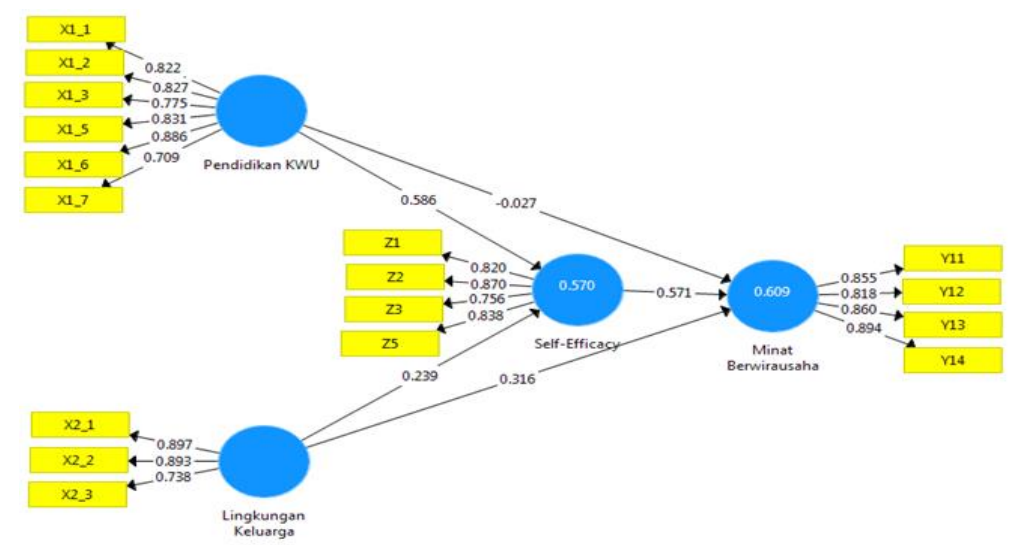

Gambar 1. Outer Model

Berdasarkan gambar 1 yang tersaji di atas ini bisa diketahui bahwa nilai factor loading pada tiap indikator pendidikan kewirausahaan (X1), lingkungan keluarga (X2), self-efficacy (Z), dan minat berwirausaha $(\mathrm{Y}) \geq 0.7$ dan hasil t-hitung lebih tinggi dari 1.960 juga hasil P- value lebih rendah dari 0.05, maka bisa ditarik kesimpulan jika tiap-tiap indikator valid serta signifikan dalam mengukur konstruknya.

Tabel 1. Hasil uji discriminant validity

\begin{tabular}{|c|c|c|c|c|}
\hline & $\begin{array}{l}\text { Lingkungan } \\
\text { Keluarga }\end{array}$ & $\begin{array}{l}\text { Minat } \\
\text { Berwirausaha }\end{array}$ & $\begin{array}{l}\text { Pendidikan } \\
\text { Kewirausahaan }\end{array}$ & $\begin{array}{l}\text { Self- } \\
\text { Efficacy }\end{array}$ \\
\hline X2 & 0.846 & & & \\
\hline $\mathbf{Y}$ & 0.640 & 0.857 & & \\
\hline X1 & 0.609 & 0.583 & 0.810 & \\
\hline $\mathbf{Z}$ & 0.595 & 0.739 & 0.731 & 0.822 \\
\hline
\end{tabular}

Sumber : data diolah oleh peneliti (2021)

Berdasarkan tabel 1 bisa ditinjau jika output loading dari tiap-tiap konstruk (0.846; $0.857 ; 0.810 ; 0.822)$ dapat diketahui nilai konstruk tiap-tiap loading lebih besar dari kontsruk lain. Sehingga bisa disimpulkan indikator pada tiap-tiap variabel sudah mencukupi Discriminant Validity.
Setelah itu dilakukan pengujian reliabilitas ini dapat dinyatakan lewat dua cara yakni meninjau composite reliability dan nilai cronbach alpha. Apabila output composite reliability dan cronbach alpha $\geq 0.60$ maka dapat dinyatakan bahwa setiap konstruk reliable (Urbach, N., \& Ahlemann, 2010).

Tabel 2. Hasil Uji Goodness Of Fit

\begin{tabular}{lcrrr}
\hline & $\begin{array}{l}\text { Cronbach's } \\
\text { Alpha }\end{array}$ & rho_A & $\begin{array}{l}\text { Composite } \\
\text { Reliability }\end{array}$ & $\begin{array}{l}\text { Average } \\
\text { Variance } \\
\text { Extracted } \\
(\boldsymbol{A V E})\end{array}$ \\
\hline Lingkungan Keluarga & 0.796 & 0.793 & 0.882 & 0.715 \\
Minat Berwirausaha & 0.879 & 0.879 & 0.917 & 0.735 \\
Pendidikan KWU & 0.894 & 0.906 & 0.919 & 0.656 \\
\hline
\end{tabular}


Jurnal PAJAR (Pendidikan dan Pengajaran)

Volume 5 Nomor 5 September 2021 | ISSN Cetak : 2580 - 8435| ISSN Online : 2614 - 1337

DOI : http://dx.doi.org/10.33578/pjr.v5i5.8417

\begin{tabular}{lcccc}
\hline Self-Efficacy & 0.839 & 0.849 & 0.893 & 0.676 \\
\hline Sumber: data diolah oleh peneliti $(2021)$ & & &
\end{tabular}

Berdasarkan tabel 2 nilai AVE pada masing - masing konstruk sesuai dengan kriteria yaitu diatas 0.50 maka dapat dinyatakan bahwa discriminant validity baik selain itu juga mempunyai reliabilitas yang baik sebab hasil cronbach's alpha dan composite reliability lebih besar 0.60

\section{Model Struktural (Inner Model)}

Untuk melakukan pengujian evaluasi inner model ada beberapa tahap yang perlu dilakukan, adapun tahap pertama yaitu melihat R-Square pada konstruk dependen, yang kedua yaitu menghitung Q-Square dengan perhitungan Stone-Geisser $Q$ Square Test (Urbach, N., \& Ahlemann, 2010).

Tabel 3. Hasil Uji $R$ Square

\begin{tabular}{lll}
\hline Variabel & $\boldsymbol{R}$ Square & $\begin{array}{l}\text { R Square } \\
\text { Adjusted }\end{array}$ \\
\hline Minat Berwirausaha & 0.609 & 0.589 \\
Self-Efficacy & 0.570 & 0.556
\end{tabular}

Sumber : data diolah peneliti (2021)

Sesuai Tabel 3 bisa diketahui hasil $R$ square pada variabel minat berwirausaha $(\mathrm{Y})$ yaitu 0.609. Selanjutnya variabel self-efficacy diperoleh hasil sejumlah 0.570 atau 57 persen ini dipengaruhi oleh pendidikan kewirausahaan dan lingkungan keluarga

Nilai $Q$-Square dilakukan guna mengukur nilai observasi yang diperoleh oleh model juga perkiraan tolok ukurnya apakah sudah baik. Adapun dalam penelitian ini nilai $Q$-Square Nya adalah

$$
\begin{aligned}
\mathrm{Q} 2 & =1-\left(1-\mathrm{R} 1^{2}\right) \quad \mathrm{x}\left(1-\mathrm{R} 2^{2}\right) \\
& =1-(1-0.609) \times(1-0.570) \\
& =1-(0.391) \quad \mathrm{x}(0.430)
\end{aligned}
$$

$$
=0.832
$$

Setelah dilakukannya Stone-Geisser $Q$ Square test dapat diketahui nilainya sebesar 0.832 . keragaman data dapat dijelaskan dari model structural yang telah dirancang sebesar 83.2 persen ini dinyatakan baik karena lebih besar dari nol (0).

\section{Uji Hipotesis}

Pengujian ini dilakukan dengan menggunakan metode bootstrapping, prosedur resampling (pengulangan sampel) ini diterapkan di

\begin{tabular}{|c|c|c|c|c|c|}
\hline & $\begin{array}{l}\text { Original } \\
\text { Sample } \\
(O)\end{array}$ & $\begin{array}{l}\text { Sample } \\
\text { Mean } \\
(M)\end{array}$ & $\begin{array}{l}\text { Standard } \\
\text { Deviation } \\
\text { (STDEV) }\end{array}$ & $\begin{array}{l}\text { T Statistics } \\
(\mid \text { OSTDEV } \mid)\end{array}$ & $\begin{array}{l}P \\
\text { Values }\end{array}$ \\
\hline X1-> Y & -0.027 & -0.023 & 0.100 & 0.267 & 0.789 \\
\hline $\mathbf{X} 2->Y$ & 0.316 & 0.306 & 0.145 & 2.179 & 0.030 \\
\hline X1 -> Z & 0.586 & 0.591 & 0.110 & 5.344 & 0.000 \\
\hline $\mathbf{X} 2->\mathrm{Z}$ & 0.239 & 0.244 & 0.118 & 2.017 & 0.044 \\
\hline$Z \rightarrow Y$ & 0.571 & 0.576 & 0.123 & 4.632 & 0.000 \\
\hline
\end{tabular}
metode dengan kalkulasi computer. Hasil uji hipotesis ditunjukan pada tabel 4 dan 5 .

Tabel 4 . Hasil Uji Path Coefficient

Sumber : data diolah oleh penliti (2021) 
Tabel 5. Hasil Uji Specific Indirect Effects

\begin{tabular}{cccccc}
\hline & $\begin{array}{c}\text { Original } \\
\text { Sample } \\
(\boldsymbol{O})\end{array}$ & $\begin{array}{c}\text { Sample } \\
\text { Mean } \\
(\boldsymbol{M})\end{array}$ & $\begin{array}{c}\text { Standard } \\
\text { Deviation } \\
(\text { STDEV })\end{array}$ & $\begin{array}{c}\text { T Statistics } \\
(\mid \text { O/STDEV })\end{array}$ & $\begin{array}{c}\boldsymbol{P} \\
\text { Values }\end{array}$ \\
\hline $\mathbf{X 1 - > Z - > Y}$ & 0.334 & 0.336 & 0.081 & 4.114 & $\mathbf{0 . 0 0 0}$ \\
$\mathbf{X 2}$->Z->Y & 0.136 & 0.145 & 0.084 & 1.613 & $\mathbf{0 . 1 0 7}$ \\
\hline
\end{tabular}

Sumber : data diolah oleh peneliti (2021)

\section{Pembahasan \\ Pengaruh pendidikan kewirausahaan terhadap minat berwirausaha}

Output pengaruh langsung pada hipotesis ini memiliki arah yang negative nilai koefisien jalur didapat -0.027 dengan t-statistic sejumlah 0.267 maka bisa disimpulkan tidak berpengaruh positif dan signifikan pendidikan kewirausahaan ke minat berwirausaha karena nilai tidak seperti kriteria dengan begitu H1 ditolak. Tidak berpengaruhnya variabel pendidikan kewirausahaan ke minat berwirausaha ini karena disebabkan ada faktor lain dari hasil penemuan peneliti faktor lingkungan keluarga ialah sebab lain yang memberi pengaruh. Pola atau cara orang tua dapat mempengaruhi seseorang dalam melakukan sesuatu termasuk berwirausaha.

Riset ini tidak sesuai riset dari Hanum (2014) bahwa untuk mendukung minat berwirausaha mahasiswa diperlukan mata kuliah kewirausahaan dan tidak sejalan dengan penelitian dari Ramadhani \& Nurnida (2017) menyatakan bahwa mata kuliah kewirausahaan berpengaruh mendorong minat. Pengetahuan tentang kewirausahaan adalah salah satu syarat dalam mendorong mahasiswa untuk berminat dalam melakukan kegiatan wirausaha (Jailani dkk., 2017). Dengan adanya pengetahuan kewirausahaan mahasiswa dapat merubah pola pikirnya sehingga tidak hanya mengandalkan ketika lulus menjadi seorang pegawai namun juga bisa menjadi seorang wirausaha. Dimasa pandemi seperti ini pengetahuan terkait wirausaha sangatlah penting dikarenakan semakin berkurangnya lapangan pekerjaan di Indonesia sehingga diharapkan dengan adanya pembelajaran wirausaha mahasiwa dapat menciptakan lapangan pekerjaan baru untuk masyarakat.
Namun pada penelitian ini pendidikan kewirausahaan kurang dapat mendorong minat berwirausaha mahasiswa, dikarenakan sarana dan prasarana kampus kurang memadai serta metode pegajaran tidak sesuai dengan harapan mahasiswa, ini senada dengan penelitian dari Dewi \& Subroto (2020), Setiawan (2018) yang menyimpulkan jika pendidikan kewirausahaan tidak berdampak ke minat berwirausaha.

Untuk mengukur variabel pendidikan kewirausahaan menggunakan indikator tujuan pendidikan, sarana dan prasarana, materi serta metode pengajaran. Tidak diterimanya hipotesis ini juga dipengaruhi oleh sarana dan prasarana yang ada di kampus kurang mendorong mahasiswa dalam berwirausaha, terdapat $14.6 \%$ responden yang menyatakan bahwa sarana dan prasarana belum maksimal dalam mendorong minat berwirausaha mahasiswa ini dikarenakan tidak adanya dukungan dalam proses pemasaran produk seperti dibuatkan wadah berupa bazar bagi mahasiswa untuk memasarkan produknya kemudian tidak adanya dukungan modal bagi tiaptiap kelompok dalam proses penciptaan produk dan kurang optimalnya seminar serta pelatihan kewirausahaan di kampus, selain dipengaruhi oleh sarana dan prasarana terdapat $12.9 \%$ responden yang menyatakan bahwa metode pengajaran yang dilakukan dosen kurang dapat menarik mahasiswa dalam mendorong semangatnya untuk berminat berwirausaha. Metode pengajaran tidak sesuai dengan harapan mahasiswa, dalam proses pembelajaran mahasiswa mengharapkan agar dosen tidak hanya memberikan pengetahuan terkait kewirausahaan namun juga memberi motivasi dengan memberikan bukti nyata menghadirkan seorang praktisi yang bergerak dibidang bisnis kemudian memberikan kiat-kiat sukses diawal proses pembelajaran agar 
mahasiswa lebih terpacu untuk belajar berwirausaha. Penelitian ini senada dengan Dewi \& Subroto (2020) fasilitas sarana dan prasarana di kampus dapat mempengaruhi minat.

\section{Pengaruh Lingkungan Keluarga Terhadap Minat Berwirausaha}

Lingkungan keluarga berpengaruh positif serta signifikan ke minat berwirausaha. Hasil koefisien jalur yakni 0.316 serta t-statistic sejumlah 2.179. Dan p-value sebesar $0.030 \leq 0.05$. Dari hasil pengujian $\mathrm{H} 2$ dinyatakan diterima. Pendidikan pertama bagi seorang anak berasal dari lingkungan keluarga, sehingga orang tua adalah contoh bagi anaknya, suasana lingkungan keluarga yang harmonis dan motivasi anggota keluarga serta cara mengarahkan anak bisa mempengaruhi keberhasilan anak (Evaliana, 2015).

Lingkungan sosial yang paling dekat bagi wirausaha adalah keluarga perannya dalam membentuk karakter wirausaha sangatlah besar. Penelitian ini menguatkan hasil yang diungkapkan Setiawan \& Sukanti (2016) lingkungan keluarga mempengaruhi minat berwirausaha, terbentuknya minat berwirausaha apabila keluarga memberikan pengaruh positif terhadap minat tersebut, baik secara langsung atau tidak sikap dan aktivitas sesama anggota keluarga akan saling mempengaruhi. Anak cenderung akan megikuti jejak orangtuanya, jika pekerjaan orang tua sebagai wiraswasta maka pola pikir anak tersebut akan dipengaruhi dan dapat menjadi salah satu penentuan dalam pemilihan pekerjaan. Penelitian ini sejalan dengan Aprilianty (2012), Ardiyani \& Kusuma (2016), Marini \& Hamidah (2014), dan Yusuf \& Kornelius (2017) yang menyimpulkan jika circle keluarga berdampak positif ke peminatan berwirausaha.

Indikator pengukuran pada circle keluarga yakni menggunakan perlakuan orang tua ke anak, keberfungsian keluarga, serta status ekonomi. Dukungan orang tua terhadap usaha anak ternyata sangat berpengaruh terhadap minat berwirausaha yang dilakukan oleh seorang anak hal ini ditunjukan dengan terdapat $80.6 \%$ responden yang menyatakan bahwa dukungan orangtua penting dalam mendorong anak untuk berminat berwirausaha. Penelitian ini selaras dengan Periera dkk. (2017) yang menyebutkan bahwa tingginya dukungan orang tua maka semakin tinggi pula tingkat minat berwirausahanya.

Anak yang hidup dalam lingkungan keluarga seorang pengusaha atau lingkungan keluarga wiraswasta akan membentuk sikap dan pemikiran yang mendalam mengenai kepercayaan akan kemampuan berwirausaha lebih awal dibanding anak yang tidak dalam lingkungan keluarga seorang wirausaha karena pengetahuan dan pembelajaran didapat sejak dini dari lingkungan keluarga.

\section{Pengaruh Pendidikan Kewirausahaan terhadap Self-Efficacy}

Pendidikan kewirausahaan berpengaruh positif dan signifikan ke self-efficacy. Pendidikan kewirausahaan pada self-efficacy memiliki koefisien jalur sebesar 0.586 serta $t$-statistic sejumlah 5.344 sehingga dapat disimpulkan H3 diterima dan pendidikan kewirausahaan berpengaruh secara positif dan signifikan ke selfefficacy.

Teori Bandura dalam Jailani dkk. (2017) mengungkapkan motivasi, minat, presepsi dan tindakan seseorang dalam melakukan sesuatu merupakan kontribusi besar dari self efficacy. Sehingga dengan adanya bekal pendidikan kewirausahaan dan self-efficacy mahasiswa dapat lebih percaya diri dalam berkarir menjadi seorang wirausaha. Self efficacy dapat mendorong seseorang dalam menyakini diri bahwa potensi yang dimilikinya dapat menjadikan rasa percaya diri lebih tinggi dalam memecahkan permasalahan atau mengerjakan tugas lebih mudah. Pendidikan kewirausahaan yang diberikan dalam pembelajaran dapat meningkatkan kepercayaan diri pada mahasiswa dalam berwirausaha.

Hal tersebut menunjukkan self-efficacy dipengaruhi oleh aktivitas-aktivitas pembelajaran dalam pendidikan kewirausahaan yang mampu meningkatkan efikasi diri mahasiswa, dengan terdapat $53.2 \%$ responden melalui pengukuran indikator tujuan pendidikan yang menyatakan bahwa setelah mengikuti pendidikan kewirausahaan dapat meningkatkan pemahaman terkait pengetahuan kewirausahaan sehingga kepercayaan diri semakin meningkat. Efikasi diri 
dapat memunculkan rasa percaya diri akan potensi yang dimiliki sehingga dapat dijadikan modal utama memulai usaha oleh sebab itu, dengan dukungan pendidikan kewirausahaan yang matang self-efficacy dapat berguna. Agar pendidikan kewirausahaan mampu menumbuhkan nilai selfefficacy diharapkan pembelajaran mahasiswa diberikan kesempatan dalam mencoba membuat suatu usaha dengan begitu dapat melatih rasa percaya serta keyakinan atas kemampuan yang dimiliki.

Penelitian ini selaras dengan Lestari \& Sukirman (2020) dalam penelitiannya yang menyatakan bahwa pendidikan kewirausahaan dengan cara parsial berdampak positif pada selfefficacy. Adapun hasil penelitian lain yang senada yaitu Mugiyatun \& Khafid (2020), Melyana \& Pujiati ( 2015), Utomo \& Asriati (2014) dan penelitian dari Anggraeni \& Nurcaya (2016) menyimpulkan jika terdapat pengaruh yang positif dan signifikan pendidikan kewirausahaan ke selfefficacy.

\section{Pengaruh Lingkungan Keluarga terhadap Self- Efficacy}

Terdapat pengaruh yang positif dan signifikan lingkungan keluarga ke self-efficacy ini ditunjukan melalui nilai koefisien jalur diperoleh sejumlah 0.239 dan juga t-statistic sejumlah 2.017 dan $\mathrm{p}$ value sebesar 0.044 hal tersebut sudah memenuhi kriteria. Berdasarkan hasil tersebut terdapat penerimaan hipotesis dengan begitu $\mathrm{H} 4$ diterima, sehingga self-efficacy dipengaruhi secara positif dan signifikan oleh variabel lingkungan keluarga. Pendidikan pertama anak berasal dari lingkungan keluarga, selain itu tumbuh kembang seorang anak juga dipengaruhi oleh faktor keluarga (Prastiwi, 2019). Lingkungan keluarga memiliki pengaruh yang besar dalam perkembangan dan pemilihan pekerjaan bagi seorang anak dimasa yang akan datang. Semakin tinggi dukungan orang tua semakin tinggi pula self-efficacy yang dimiliki anak pada dirinya yang dapat mendorong anak untuk memilih sesuatu yang diminati.

Cara mendidik anak dalam keluarga juga mempengaruhi kepribadian seorang anak, budi pekertinya serta watak dalam diri tiap manusia, selain itu juga dapat menumbuhkan self-efficacy pada kepribadian anak. Self-efficacy merupakan kemahiran dan keyakinan seseorang dalam melakukan serangkaian kegiatan di situasi tertentu. Tingginya efikasi diri yang dimiliki seseorang maka dapat menjadikan orang tersebut memiliki upaya untuk mengerjakan tugas yang tidak mudah, serta memiliki kegigihan, selalu tenang dalam menghadapi tugas dan selalu menggunakan pemikiran secara analitis (Mugiyatun \& Khafid, 2020). Lingkungan keluarga menjadi pemicu timbulnya minat berwirausaha, biasanya jika seorang anak terlahir dari pekerjaan orang tua menjadi wirausaha pastinya anak tersebut juga akan meneruskan jejak orang tuanya. Karena dalam lingkungan keluarga anak mendapatkan dorongan, perhatian, kasih sayang, dan bimbingan serta keteladanan oleh orang tua pada anaknya sehingga cara berperilaku serta bertindak tidak jauh beda dari lingkungan keluargannya.

Peran orang tua dalam menimbulkan minat berwirausaha dipengaruhi oleh cara mengasuh dan mengarahkan anak (Utomo \& Asriati, 2014), terlebih jika orang tuanya adalah seorang wirausahawan, maka anak tersebut akan memiliki efikasi diri terhadap kewirausahaan sehingga diharapkan dapat memiliki minat serta mengetahui peluang usaha yang sesuai dengan keinginannya. Senada juga hasil penelitian Lestari \& Sukirman (2020), Patrikha \& Dewi (2016) dan Kurniawan dkk. (2016) yang menyebutkan self-efficacy dipengaruhi secara positif oleh lingkungan keluarga.

\section{Pengaruh Self Efficacy Terhadap Minat berwirausaha}

Self-efficacy berpengaruh positif serta signifikan ke minat berwirausaha, nilai koefisien jalur pada uji hipotesis ini sebesar 0.571 serta tstatistik sebesar 4.632 dengan demikian terdapat penerimaan $\mathrm{H} 5$ sebab t hitung lebih tinggi dari $\mathrm{t}$ tabel hingga self-efficacy mempunyai dampak yang positif, $p$ value sejumlah 0.000 lebih rendah dari 0.05 dan dinyatakan signifikan ke minat berwirausaha.

Dalam Theory of Planned Behavior (TPB) pengambilan pilihan seseorang menjadi wirausaha didasari oleh sebab dalam diri yakni self-efficacy hal ini artinya jika faktor kepribadian (self- 
efficacy) ikut andil dalam mempengaruhi mahasiswa untuk berminat menjadi wirausaha. Pemikiran seseorang mengenai seberapa bisa diri berguna pada kondisi tertentu merupakan selfefficacy. Penentuan sikap mahasiswa dalam menguasai kemampuan untuk menjadi wirausaha dapat dilakukan dengan mengenali diri, dan nantinya mahasiswa tersebut akan memiliki minat berwirausaha setelah lulus atau bahkan ketika masih mengenyam pendidikan. Kesempatan seseorang untuk menjadi wirausaha sukses bergantung pada seberapa tinggi self-efficacy yang dimiliki pada dirinya dengan begitu, mahasiswa yang merasa dirinya bisa berwirausaha biasanya memiliki self-efficacy tinggi pada kewirausahaan sehingga makin tinggi peminatan mahasiswa ketika berwirausaha. Dalam riset terdahulu yang dilakukan oleh Marini \& Hamidah (2014) minat berwirausaha didasari baik dengan cara bersamasama atau sendiri-sendiri oleh variabel selfefficacy, circle keluarga, serta circle sekolah. Riset ini senada pada penelitian dari Yanti (2019) yang menyimpulkan jika secara parsial self-efficacy ada dampak positif pada peminatan berwirausaha lain dari itu riset ini juga sesuai dengan Puspitaningsih (2017), Evaliana (2015) dan Pamungkas \& Mustikawati (2018) menyatakan bahwa minat berwirausaha dipengaruhi oleh self-efficacy.

\section{Pengaruh Pendidikan Kewirausahaan terhadap Minat Berwirausaha dimediasi Self-Efficacy}

Berdasarkan pengujian hipotesis yang dilihat dari Specific Indirect Effects bahwa variabel self-efficacy merupakan variabel intervening dari pendidikan kewirausahaan terhadap minat berwirausaha, nilai dari pengaruh tidak langsung sebesar 0.334 atau $33.4 \%$ dengan tstatistic 4.114 serta nilai $\mathrm{P}$ value 0.000 sehingga $\mathrm{H} 6$ diterima variabel pendidikan kewirausahaan ke minat berwirausaha yang dimediasi oleh variabel self efficacy berpengaruh positif serta signifikan. Penambahan variabel mediasi self-efficacy ini sangat diperlukan jika dilihat dari direct path nilai koefisien jalur diperoleh 0,027 dan t-statistic sebesar 0,281 maka disimpulkan bahwa Pendidikan Kewirausahaan tidak berpengaruh pada Minat Berwirausaha
Nilai indirect path lebih besar dari nilai direct path artinya besar pengaruh ini menunjukkan peran variabel mediasi self-efficacy berperan penuh atau disebut dengan full mediation dalam memediasi dengan cara sempurna antara pengaruh pendidikan kewirausahaan pada minat berwirausaha. Pendidikan kewirausahaan perannya dalam menciptakan mahasiswa memiliki rasa minat berwirausaha ini tidak serta merta dilakukan sendiri, namun terdapat faktor lain yang menyebabkan mahasiswa memiliki minat berwirausaha, faktor lain tersebut yaitu selfefficacy ini menguatkan penelitian dari Anggraeni \& Nurcaya (2016). Self-efficacy memiliki peran penting juga dalam membentuk keyakinan dalam berminat berwirausaha, dengan adanya pendidikan terkait kewirausahaan mahasiswa memiliki pengetahuan lebih dalam berwirausaha dengan begitu kepercayaan diri terkait wirausaha juga semakin tinggi hal ini dapat meningkatkan mahasiswa berminat berwirausaha.

Output ini selaras dengan Maharani \& Khalikussabir (2020) yang menyimpulkan jika pendidikan kewirausahaan ke peminatan berwirausaha dimediasi self-efficacy mempengaruhi secara positif dan signifikan, ini juga sejalan dengan Indriyani \& Subowo (2019) menyatakan bahwa self-efficacy mempengaruhi keyakinan dalam diri mahasiswa bahwa keberhasilan usaha yang dilakukan memiliki penekanan self-efficacy melalui dorongan, pengetahuan dan kreativitas mahasiswa. output ini senada dengan Mugiyatun \& Khafid (2020), Jailani dkk. (2017) dan Utomo \& Asriati (2014) menyatakan bahwa self-efficacy sebagai variabel mediasi memiliki dampak secara positif dan signifikan pada pendidikan kewirausahaan ke minat berwirausaha.

\section{Pengaruh Lingkungan keluarga terhadap Minat Berwirausaha dimediasi Self-Efficacy}

Berdasarkan pengujian hipotesis terhadap H7 yang berbunyi diduga self-efficacy memediasi secara signifikan pengaruh lingkungan keluarga terhadap minat berwirausaha ditolak dikarenakan koefisien jalur 0.136 dengan nilai t-statistic 1.613 dan $\mathrm{p}$ value sebesar 0.107. Rendahnya nilai indirect path dari nilai direct path menunjukkan 
bahwa peran variabel mediasi self-efficacy tidak ada efek mediasi terhadap variabel Lingkungan keluarga (X2) ke Minat Berwirausaha (Y).

Dikarenakan peran lingkungan keluarga dirasa sudah berperan secara langsung terhadap minat berwirausaha tanpa melalui self-efficacy, ini ditunjukan dengan terdapat $75.8 \%$ responden melalui pengukuran indikator keberfungsian keluarga yang menyatakan kedua orang tua berperan dalam memotivasi anak berwirausaha, selain itu terdapat $74.2 \%$ melalui indikator perlakukan orang tua ke anak menunjukan bahwa didikan orangtua yang tidak membiasakan anaknya untuk bergantung pada orang lain mampu mendorong anak tersebut untuk berusaha sendiri mewujudkan impian melalui berwirausaha. Pengaruh lingkungan keluarga sendiri terdapat pengaruh positif dan negatifnya jika mahasiswa itu ada di lingkungan keluarga yang kebanyakan menjadi wirausaha maka mahasiswa tersebut yakin untuk menjadi wirausaha sebagai pilihan karir mengikuti jejak lingkungan keluarganya. Namun penelitian yang diungkapkan oleh Indriyani \& Subowo (2019) lingkungan keluarga biasanya juga memberikan dampak negatif terkait minat anak berwirausaha, orang tua cenderung lebih bangga anak menjadi seorang pegawai karena dirasa resiko yang dihadapi akan jauh lebih rendah dibanding menjadi seorang wirausahawan dengan tidak adanya dukungan orang tua anak menjadi tidak memiliki keyakinan dalam berwirausaha. Semakin rendah dukungan lingkungan keluarga semakin rendah pula keberanian dan keyakinan anak untuk berwirausaha. Hal ini artinya lingkungan keluarga sudah berperan secara langsung dalam membentuk karakter anak untuk memulai hal yang akan dicapai anak berdasarkan pemikiran rasional dan mengikuti urutan berpikir yang diarahkan pernyataan tersebut memperkuat theory of planned bahaviour yang mengungkapkan putusan dalam menampilkan tingkah laku tertentu berasal dari hasil berpikir rasional yang diarahkan pada tujuan tertentu untuk mengikuti tata urutan berpikir.

Hasil penelitian ini tidak selaras dengan penelitian Kurniawan dkk. (2016) yang menyebutkan bahwa minat berwirausaha dipengaruhi oleh lingkungan keluarga yang dimediasi self-efficacy, juga tidak selaras dengan
Indriyani \& Subowo (2019), Utomo \& Asriati (2014), Mugiyatun \& Khafid (2020) yang menyatakan bahwa self-efficacy dapat memediasi dampak lingkungan keluarga ke minat berwirausaha.

\section{SIMPULAN DAN REKOMENDASI}

Berdasarkan pemaparan dan penjelasan output riset peneliti dapat menyimpulkan bahwa Hasil uji hipotesis menyimpulkan variabel pendidikan kewirausahaan (X1) ke minat berwirausaha (Y) tidak berpengaruh artinya menolak H1 dan menerima H0. Hasil uji hipotesis menyimpulkan variabel lingkungan keluarga (X2) terhadap minat berwirausaha (Y) memiliki pengaruh secara positif serta signifikan artinya menerima $\mathrm{H} 2$ dan menolak H0. Hasil uji hipotesis menyimpulkan variabel pendidikan kewirausahaan (X1) ke self-efficacy (Z) memiliki pengaruh sehingga hasil menunjukkan bahwa uji hipotesis menerima $\mathrm{H} 3$ dan menolak H0. Hasil uji hipotesis menyimpulkan jika variabel lingkungan keluarga (X2) terhadap self-efficacy (Z) mempengaruhi secara positif dan signifikan artinya menerima $\mathrm{H} 4$ dan menolak H0. Hasil uji hipotesis menyimpulkan variabel self-efficacy $(\mathrm{Z})$ terhadap minat berwirausaha (Y) memiliki pengaruh sehingga hasil menunjukkan bahwa uji hipotesis menerima $\mathrm{H} 5$ dan menolak $\mathrm{H} 0$.

Hasil uji hipotesis menyatakan bahwa variabel pendidikan kewirausahaan (X1) ke minat berwirausaha $(\mathrm{Y})$ yang dimediasi self-efficacy $(\mathrm{Z})$ mempengaruhi secara positif dan signifikan. maka peneliti menyimpulkan self-efficacy (Z) dapat memediasi pendidikan kewirausahaan (X1) ke minat berwirausaha $(\mathrm{Y})$ maka riset menerima $\mathrm{H} 6$ dan menolak H0. Hasil uji hipotesis menyatakan bahwa variabel lingkungan keluarga (X2) terhadap minat berwirausaha $(\mathrm{Y})$ yang dimediasi selfefficacy (Z) tidak ada dampak yang positif dan signifikan, peran self-efficacy (Z) menunjukkan tidak ada efek mediasi. Maka peneliti menyimpulkan variabel lingkungan keluarga (X2) ke minat berwirausaha $(\mathrm{Y})$ yang dimediasi selfefficacy ( $Z$ ) tidak berpengaruh dan signifikan artinya menolak $\mathrm{H} 7$ dan menerima H0. Ada sejumlah penyebab dan faktor-faktor yang memberi secara langsung pengaruh peminatan 
berwirausaha maka dari itu peneliti hanya terbatas pada tiga penyebab utama dari faktor itu yaitu pengetahuan entrepreneurship, lingkup keluarga dan self-efficacy. Serta saat penentuan jumlah responden hanya terbatas pada mahasiswa program studi pendidikan administrasi perkantoran universitas negeri Surabaya angkatan 2018.

Hasil riset ini dapat dijadikan pertimbangan dan masukan bagi perguruan tinggi dalam mengoptimalkan dan memaksimalkan fasilitas dari sarana dan prasarana yang diberikan bagi mahasiswa guna mengoptimalkan dan memaksimalkan hasil yang diperoleh dan dihasilkan. Serta dapat dijadikan pertimbangan dan evaluasi dalam memilih ataupun mengkaji materi kewirausahaan yang akan disampaikan dan juga djadikan bahan ajar kepada mahasiswa dan dapat dijadikan sumber referensi acuan ketika penelitian di bidang kewirausahaan.

Adapun masukan yang bisa disampaikan dan disajikan pada pemaparan dan juga pada hasil penelitian ini sebagai berikut: (1) Sebaiknya sesudah lulus mahasiswa lebih bisa memaksimalkan dan mengoptimalkan peluang dan kesempatan usaha guna mendirikan lapangan pekerjaan daripada memburu lapangan pekerjaan (2) Diharapkan terdapatnya bertambahnya teknik pengajaran dari segi materi ataupun metode pengajaran, fasilitas dan akomodasi yang mampu mendorong dan memotivasi aktivitas berwirausaha (3) Selanjutnya bagi peneliti, perlu memperhatikan variabel yang digunakan agar mendapat hasil dan output yang diharapkan, selain itu kemahiran dan keterampilan dalam membuat kuesioner dan jadi salah satu hal yang penting agar mendapat hasil yang akurat dan efektif.

\section{DAFTAR PUSTAKA}

Aini, S. N., Purwana ES., D., \& Saptono, A. (2015). Pengaruh Lingkungan Keluarga Dan Efikasi Diri Terhadap Motivasi Berwirausaha Pada Mahasiswa Fakultas Ekonomi Universitas Negeri Jakarta. Jurnal Pendidikan Ekonomi Dan Bisnis (JPEB), $3(1)$, 22. https://doi.org/10.21009/jpeb.003.1.2
Anggraeni, D., \& Nurcaya, I. (2016). Peran Efikasi Diri Dalam Memediasi Pengaruh Pendidikan Kewirausahaan Terhadap Niat Berwirausaha. E-Jurnal Manajemen Universitas Udayana, 5(4), 241653.

Aprilianty, E. (2012). Pengaruh kepribadian wirausaha, pengetahuan kewirausahaan, dan lingkungan terhadap minat berwirausaha siswa SMK. Jurnal Pendidikan Vokasi, 2(3), 311-324. https://doi.org/10.21831/jpv.v2i3.1039

Ardiyani, N., \& Kusuma, A. (2016). Pengaruh Sikap, Pendidikan Dan Lingkungan Keluarga Terhadap Minat Berwirausaha. E-Jurnal Manajemen Universitas Udayana, 5(8), 5155-5183.

Badan Pusat Statistik. (2020). Keadaan Ketenagakerjaan Jawa Timur, Agustus 2020. 1-17.

Dewi, T., \& Subroto, W. (2020). Pengaruh Pembelajaran Kewirausahaan, Motivasi Berwirausaha Dan Status Sosial Ekonomi Orang Tua Terhadap Minat Berwirausaha Mahasiswa. Jurnal Pendidikan Ekonomi (JUPE), 8(2), 62-69.

Evaliana, Y. (2015). Pengaruh Efikasi Diri Dan Lingkungan Keluarga Terhadap Minat Berwirausaha Siswa. JPBM (Jurnal Pendidikan Bisnis Dan Manajemen), 1(1), 53-60.

Fitriani et al. (2012). Faktor-Faktor Yang Mempengaruhi Minat Berwirausaha Pada Siswa Kelas Xii Smk Negeri 1 Kandeman Kabupaten Batang Tahun 2011/2012. Economic Education Analysis Journal, 1(2).

Franita, R. (2016). Analisa Pengangguran Di Indonesia. Jurnal Ilmu Pengetahuan Sosial, $\quad 1, \quad 88-93 . \quad$ http://jurnal.umtapsel.ac.id/index.php/nusantara/article/vi ewFile/97/97

Hair Jr, J. F., Hult, G. T. M., Ringle, C., \& Sarstedt, M. (2014). A primer on partial least squares structural equation modeling (PLS-SEM). Sage publications.

Hanum, A. N. (2014). Pengaruh Mata Kuliah Kewirausahaan Terhadap Minat 
Mahasiswa Menjadi Wirausaha. Jurnal Unimus, 1-13.

Harjanto, T. (2014). Pengangguran dan pembangunan nasional. Jurnal Ekonomi, $2(2), 67-77$.

Indriyani, I., \& Subowo. (2019). Pengaruh Pengetahuan Kewirausahaan dan Lingkungan Keluarga Terhadap Minat Berwirausaha Melalui Self-Efficacy. Economic Education Analysis Journal, 8(2), $\quad$ 470-484. https://doi.org/10.15294/eeaj.v8i2.31493

Jailani, M., Rusdarti, \& Sudarma, K. (2017). Pengaruh Kewirausahaan, Motivasi Belajar, Sosial Ekonomi Orang Tua Dan Self Efficacy Terhadap Minat Berwirausaha Siswa. Journal of Economic Education, 6(1), 52-59.

Kurniawan, A., Khafid, M., \& Pujiati, A. (2016). Pengaruh Lingkungan Keluarga, Motivasi, dan Kepribadian Terhadap Minat Wirausaha Melalui Self Efficacy. Journal of Economic Education, 5(1), 100-109.

Lestari, Y. P., \& Sukirman, S. (2020). Pengaruh Self Efficacy sebagai Mediasi dari Pengaruh Pendidikan Kewirausahaan dan Lingkungan Keluarga terhadap Minat Berwirausaha. Economic Education Analysis Journal, 9(2), 615-633.

Maharani, A., Widarko, A., \& Khalikussabir, K. (2020). Pengaruh Pendidikan Kewirausahaan, Motivasi Berprestasi, Dan Status Sosial Ekonomi Orang Tua Terhadap Minat Berwirausaha Dengan Self Efficacy Sebagai Variabel Intervening. Jurnal Ilmiah Riset Manajemen, 9(12).

Marini, C. K., \& Hamidah, S. (2014). Pengaruh self-efficacy, lingkungan keluarga, dan lingkungan sekolah terhadap minat berwirausaha siswa SMK jasa boga. Jurnal Pendidikan Vokasi, 4(2), 195-207. https://doi.org/10.21831/jpv.v4i2.2545

Melyana, I. P., \& Pujiati, A. (2015). Pengaruh Sikap Dan Pengetahuan Kewirausahaan Terhadap Kesiapan Berwirausaha Melalui Self-Efficacy. Journal of Economic Education, 4(1), 8-13.
Mugiyatun, M., \& Khafid, M. (2020). Pengaruh Prakerin, Pendidikan Kewirausahaan, dan Lingkungan Keluarga dengan Self Efficacy sebagai Variabel Intervening terhadap Minat Berwirausaha. Economic Education Analysis Journal, 9(1), 100 118.

Mutmainnah, S., Siregar, E., \& Sitanggang, G. (2020). Pengaruh Buku Manajemen Arsip Perguruan Tinggi Terhadap Hasil Belajar Kearsipan Mahasiswa Administrasi Perkantoran. Efisiensi - Kajian Ilmu Administrasi, 17(1), 34-41.

Pamungkas, A. P., \& Mustikawati, R. I. (2018). Pengaruh Self Efficacy, Pendidikan Kewirausahaan Dan Ekspektasi Pendapatan Terhadap Minat Berwirausaha Mahasiswa Program Studi Akuntansi the Influence of Self Efficacy, Entrepreneurship Education, and Earning Expectation Towards the Studentsinterest of. Jurnal Profita: Kajian Ilmu Akuntansi, 6(3).

Patrikha, F. D., \& Dewi, R. M. (2016). Pengaruh pendidikan kewirausahaan dalam keluarga dengan mediasi self-efficacy terhadap minat berwirausaha siswa smk (smea) di Kota Malang. Pluralisme Dalam Ekonomi Dan Pendidikan, 430-437.

Periera, A., Mashabi, N. A., \& Muhariati, M. (2017). Pengaruh Dukungan Orangtua terhadap Minat Anak dalam berwirausaha (Pada Siswa SMK Strada Koja, Jakarta Utara). JKKP (Jurnal Kesejahteraan Keluarga Dan Pendidikan), 4(02), 70-76.

Prastiwi, N. J. (2019). Peran Efikasi Diri Dalam Memediasi Pengaruh Pendidikan Kewirausahaan Dan Lingkungan Keluarga Terhadap Niat Berwirausaha. (Doctoral Dissertation, Universitas Ahmad Dahlan).

Puspitaningsih, F. (2017). Pengaruh Efikasi Diri Dan Pengetahuan Kewirausahaan Terhadap Minat Berwirausaha Melalui Motivasi. Jurnal Ekonomi Pendidikan Dan Kewirausahaan, 2(2), 223-235.

Rahmadi, A. N., \& Heryanto, B. (2016). Analisis Faktor-Faktor Yang Mempengaruhi Minat Berwirausaha Pada Mahasiswa Program 
Studi Manajemen Fakultas Ekonomi Universitas Kadiri. Ekonika: Jurnal Ekonomi Universitas Kadiri, 1(2), 153169.

https://doi.org/10.30737/ekonika.v1i2.13

Ramadhani, N. T., \& Nurnida, I. (2017). Pengaruh mata kuliah kewirausahaan terhadap minat berwirausaha mahasiswa. Jurnal Ecodemica: Jurnal Ekonomi, Manajemen, Dan Bisnis, 1(1), 89-97.

Setiawan, D., \& Sukanti, S. (2016). Pengaruh Ekspektasi Pendapatan, Lingkungan Keluarga Dan Pendidikan Kewirausahaan Terhadap Minat Berwirausaha. Jurnal Profita: Kajian Ilmu Akuntansi, 4(7).

Setiawan, D. Y. (2018). Pengaruh Perilaku Proaktif, Lingkungan Keluarga Dan Pendidikan Kewirausahaan Terhadap Minat Berwirausaha Mahasiswa Stie Putra Bangsa Kebumen.

Sugiyanti, R. (2019). Pengaruh Pendidikan Kewirausahaan, Praktik Kerja Industri, Dan Lingkungan Sosial Terhadap Minat Berwirausaha Dengan Mediasi (Doctoral Dissertation, UNNES). https://lib.unnes.ac.id/35902/

Sugiyono. (2015). Metode Penelitian Kuantitatif, Kualitatif, dan $R \& D$. Bandung: ALFABETA.

Suryana. (2006). Pedoman Praktis: Kiat dan Proses Menuju Sukses. Salemba Empat.

Urbach, N., \& Ahlemann, F. (2010). Structural Equation Modeling In Information systems Research Using Partial Least Squares. Journal of Information Technology Theory and Application, 11(2), 5-40.

Utomo \& Asriati, N. (2014). Pengaruh Pendidikan Kewirausahaan Dalam Keluarga Dan Di Sekolah Terhadap Minat Berwirausaha Dengan Mediasi Self-Efficacy Siswa Kelas Xi. (Doctoral Dissertation, Tanjungpura University).

Wibowo, E. W. (2017). Evaluasi Pembelajaran Matakuliah Kewirausahaan Berbasis Proyek Pada Politeknik Lp3I Jakarta Kampus Pasar Minggu. Jurnal Lentera Bisnis, 5(2), 45.
Yanti, A. (2019). Pengaruh Pendidikan Kewirausahaan, Self Efficacy, Locus of Control dan Karakter Wirausaha Terhadap Minat Berwirausaha. Maneggio: Jurnal Ilmiah Magister Manajemen, 2(2), 268283.

https://doi.org/10.30596/maneggio.v2i2.3 774

Yusuf, M., Natsir, S., \& Kornelius, Y. (2017). Pengaruh Kepribadian Dan Lingkungan Keluarga Terhadap Minat Berwirausaha Mahasiswa Manajemen Fakultas Ekonomi Universitas Tadulako. Jurnal Ilmu Manajemen Universitas Tadulako, 3(3), 299-308. 